\title{
CALCIUM AS SALINITY MITIGATOR ON THE PRODUCTION COMPONENTS OF PASSION FRUIT CULTIVATED IN PROTECTED PITS ${ }^{1}$
}

\author{
MARLENE ALEXANDRINA FERREIRA BEZERRA ${ }^{2 *}$, LOURIVAL FERREIRA CAVALCANTE ${ }^{2}$, FRANCISCO \\ THIAGO COELHO BEZERRA ${ }^{2}$, WALTER ESFRAIN PEREIRA ${ }^{2}$, EXPEDITO CAVALCANTE DO NASCIMENTO \\ $\mathrm{NETO}^{3}$
}

\begin{abstract}
The high rate of evaporation and the limitation of water, in quantity and quality, require the search for strategies that enable the sustainability of agriculture in the world. The experiment was carried out to evaluate the effects of water salinity, lateral protection of the pits and calcium doses on the production components of passion fruit cv. BRS GA1. The treatments were arranged in a $2 \times(2 \times 5)$ split plot, corresponding to water salinity $\left(0.3\right.$ and $\left.4.0 \mathrm{dS} \mathrm{m}^{-1}\right)$ in the main plot, and combinations between lateral protection of the pits (without and with) and calcium doses $\left(0,30,60,90\right.$ and $\left.120 \mathrm{~kg} \mathrm{ha}^{-1}\right)$ in the subplots. Number of productive branches, indices of early ripening and concentrated cropping, calculated from the weekly yields, number of fruits per plant, average fruit weight and yield were evaluated. The increase in electrical conductivity of irrigation water delays harvest and reduces the number of fruits per plant, fruit weight and yield of passion fruit. The lateral protection of the pits did not have a positive effect on the cultivation of passion fruit irrigated with saline water. Calcium dose of $60 \mathrm{~kg} \mathrm{ha}^{-1}$ in the Entisol with low content of this macronutrient attenuates the effects of irrigation with saline water, increasing the yield of yellow passion fruit.
\end{abstract}

Keywords: Passiflora edulis. Salt stress. Calcium nitrate.

\section{CÁLCIO COMO MITIGADOR DA SALINIDADE NOS COMPONENTES PRODUTIVOS DE MARACUJAZEIRO-AMARELO CULTIVADO EM COVAS PROTEGIDAS}

\begin{abstract}
RESUMO - A elevada taxa de evaporação e a limitação de água, em quantidade e qualidade, requerem a busca de estratégias que viabilizem a sustentabilidade da atividade agrícola no mundo. $\mathrm{O}$ experimento foi desenvolvido para avaliar os efeitos da salinidade da água, da proteção lateral das covas e doses de cálcio nos componentes de produção do maracujazeiro-amarelo cv. BRS GA1. Os tratamentos foram arranjados em parcela subdividida no esquema $2 \times(2 \times 5)$ correspondente a salinidade da água $\left(0,3\right.$ e $\left.4,0 \mathrm{dS} \mathrm{m} \mathrm{m}^{-1}\right)$, parcela principal, e as subparcelas às combinações entre proteção lateral das covas (sem e com) e doses de cálcio ( 0 , $30,60,90$ e $120 \mathrm{~kg} \mathrm{ha}^{-1}$ ). Foram avaliados o número de ramos produtivos, índices de amadurecimento precoce e de cultivo concentrado, número de frutos por planta, massa média de frutos e produtividade. O aumento da condutividade elétrica da água de irrigação retarda a colheita e reduz o número de frutos por planta, a massa dos frutos e a produtividade do maracujazeiro. A proteção lateral das covas não exerceu efeitos positivos no cultivo de maracujazeiro irrigado com água salina. A dose de $60 \mathrm{~kg} \mathrm{ha}^{-1}$ de cálcio em Neossolo Regolítico com baixo teor deste macronutriente atenua os efeitos da irrigação com água salina, aumentando a produtividade do maracujazeiro-amarelo.
\end{abstract}

Palavras-chave: Passiflora edulis. Estresse salino. Nitrato de cálcio.

\footnotetext{
"Corresponding author

${ }^{1}$ Received for publication in $10 / 31 / 2019$; accepted in 01/27/2020.

${ }^{2}$ Post-Graduate Program in Agronomy, Universidade Federal da Paraíba, Areia, PB, Brazil; marlene_agro@hotmail.com - ORCID: 00000002-5108-836X, lofeca@cca.ufpb.br - ORCID: 0000-0002-8827-4713, bezerra_ftc@yahoo.com.br - ORCID: 0000-0002-9185-2641, walterufpb@yahoo.com.br - ORCID: 0000-0003-1085-0191.

${ }^{3}$ Post-Graduate Program in Plant Science, Universidade Federal de Viçosa, Viçosa, MG, Brazil; cav.expedito@gmail.com - ORCID: 00000002-0330-315X
} 


\section{INTRODUCTION}

Brazil is the world's largest producer of passion fruit (FALEIRO; JUNQUEIRA, 2016), with the Northeast region leading the national production, followed by the Southeast, South, North and Midwest regions (IBGE, 2018). However, despite being the largest producing region, the Brazilian Northeast has one of the lowest productivities, $112,886 \mathrm{~kg} \mathrm{ha}^{-1}$ (IBGE, 2018), much lower than the production potential of passion fruit, which is 50,000 $\mathrm{kg} \mathrm{ha} \mathrm{ha}^{-1}$ (FALEIRO; JUNQUEIRA, 2016). The spatial-temporal irregularity of the rains, in many cases associated with the low quality of water due to excess salts, compromises agricultural activity in the semiarid regions, which encompasses most of the Brazilian Northeast. Excess salts causes reduction in the osmotic potential of the soil solution, hampering absorption and consequently leading to toxic effects (TAIZ et al., 2017).

Passion fruit can be irrigated using water with electrical conductivity of up to $2.3 \mathrm{dS} \mathrm{m} \mathrm{m}^{-1}$, maintaining $90 \%$ of its production potential (HOLANDA et al., 2016). However, the increase in irrigation water salinity can reduce the production of productive branches (FREIRE et al., 2012), length of the internodes of the branches, the amount of floral buds (DIAS et al., 2013), the production and weight of fruits (DIAS et al., 2012; SOUZA et al., 2018), consequently reducing passion fruit yield. These effects are directly related to a reduction in water consumption by passion fruit (FREIRE et al., 2011).

Thus, it is necessary to adopt preventive measures that reduce the demand for irrigation water, hence minimizing the addition of salts in the soil. Potential options include the lining/protection of pits, which conserves soil moisture by decreasing the lateral water flow (CAVALCANTE et al., 2005a). These authors, despite observing greater conservation of moisture in laterally lined pits, found no effect on passion fruit yield. On the other hand, for Cavalcante et al. (2005b), the increase in the lined faces of the pits promotes an increase in fruit production and yield of passion fruit. Lateral lining/ protection of the pits, or more precisely of the root environment of the plants, consists of a physical barrier with waterproof material inserted in the soil (CAVALCANTE et al., 2005a), so as not to compromise root growth and development and prevent lateral water flow.

Adequate supply of nutrients can also favor plants in stressful situations (BEZERRA et al., 2019). As an example, it is possible to mention calcium, an essential element to plants, which can attenuate stress (TIAN et al., 2015; TAIZ et al., 2017). Fernandes et al. (2010) recommend the application of calcium nitrate to reduce salt stress. In the soil, calcium competes directly with sodium for adsorption sites (FONTENELE et al., 2014) and may reduce the predominance of this ion. In the plant, calcium is directly related to the integrity of the plasma membrane of the cells (TAIZ et al., 2017). Under stress, calcium acts as a signaling agent, amplifying the stress signal by increasing its concentration in the cell cytosol (KADER; LINDBERG, 2010; ALDON et al., 2018). Passion fruit yield is increased with calcium application (CAVALCANTE et al., 2014, 2015).

Therefore, the objective with this study was to evaluate the lateral protection of the pits with highresistance plastic film associated with calcium application to mitigate the effects of irrigation water salinity on the production components of passion fruit.

\section{MATERIAL AND METHODS}

The experiment was conducted between November 2015 and July 2016, at the Macaquinhos

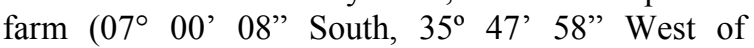
Greenwich and $564 \mathrm{~m}$ altitude), in the municipality of Remígio, Paraíba, Brazil. The municipality is inserted in the climate zone As', according to Köppen's classification, which means tropical climate with rains from March to August (ALVARES et al., 2013).

The meteorological conditions at the Macaquinhos farm along the cultivation of BRS GA1 passion fruit were monitored daily with measurements of temperature, relative humidity, rainfall and reference evapotranspiration (Figure 1). Air temperature and relative humidity were recorded every hour with an HT-70 datalogger manufactured by Instrutherm $\AA$. Daily average of air temperature was calculated by the mean of extreme temperatures, whereas the average relative humidity was calculated through the mean of daily readings. Rainfall was quantified using a rain gauge and reference evapotranspiration was determined based on the Class A pan evaporation multiplied by the tank coefficient $(0.75)$.

The soil of the experimental area was classified as Entisol with loamy sand texture, with the following attributes of fertility in the $0-20 \mathrm{~cm}$ layer: $\mathrm{pH}$ in water, 4.58; calcium, magnesium, potassium, sodium, sum of bases, potential acidity $\left(\mathrm{H}^{+}+\mathrm{Al}^{3+}\right)$ and cation exchange capacity of 1.92 , $0.48,0.08,0.05,2.53,1.30$ and $3.83 \mathrm{cmol}_{\mathrm{c}} \mathrm{dm}^{-3}$, respectively; base saturation, 66.1\%; phosphorus, $10.6 \mathrm{mg} \mathrm{dm}^{-3}$; organic matter, $5.1 \mathrm{~g} \mathrm{~kg}^{-1}$, and electrical conductivity of the saturation extract, 0.82 $\mathrm{dS} \mathrm{m}^{-1}$. This same layer also showed: bulk and particle densities of 1.57 and $2.64 \mathrm{~g} \mathrm{~cm}^{-3}$, sand, silt, total clay and water-dispersible clay of $842,92,66$ and $13 \mathrm{~g} \mathrm{~kg}^{-1}$, respectively, flocculation degree of $80.3 \%$, and total porosity of $0.41 \mathrm{~m}^{3} \mathrm{~m}^{-3}$. 


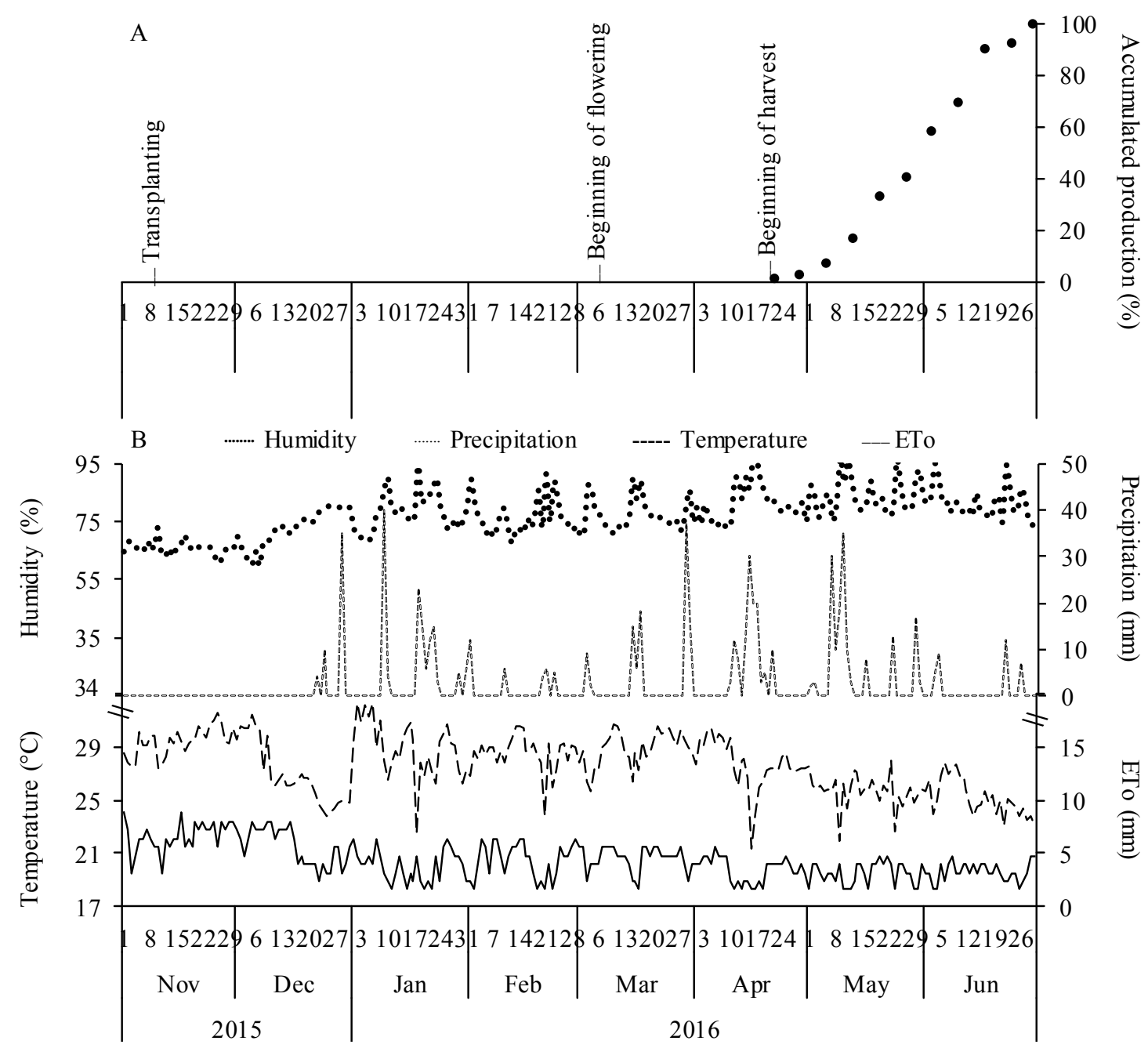

Figure 1. Stages of the experiment (A) and average daily values of air temperature and relative humidity, rainfall and reference evapotranspiration (ETo) at Macaquinhos farm, municipality of Remígio, Paraíba, Brazil (B).

Treatments were arranged in split plot, in $2 \mathrm{x}$ $(2 \times 5)$ scheme, with the main plot corresponding to the levels of irrigation water electrical conductivity $\left(0.3\right.$ and $\left.4.0 \mathrm{dS} \mathrm{m} \mathrm{m}^{-1}\right)$ and the subplots to the combinations of lateral protection of the pits (without and with) with calcium doses $(0,30,60,90$ and 120 $\left.\mathrm{kg} \mathrm{ha}{ }^{-1}\right)$. Treatments were distributed in four randomized blocks and the experimental unit consisted of four plants.

The passion fruit (BRS GA1) orchard was planted at density of 1,666 plants per hectare, in the spatial arrangement of $2 \mathrm{~m}$ between rows and $3 \mathrm{~m}$ between plants in the row. The pits were opened with dimensions of $40 \times 40 \times 40 \mathrm{~cm}$. Treatments with lateral protection of the pits used high-resistance plastic film $(320 \mu)$, installed within a $50 \mathrm{~cm}$ radius from the center of the pit and at $45 \mathrm{~cm}$ depth, aiming to reduce water losses by lateral infiltration. Seedlings were transplanted on November 11, 2015, and the plant training system was a single wire trellis consisting of a flat wire no. 12 installed at $2.2 \mathrm{~m}$ height at the top of the posts.

Fertilization followed the recommendations of Borges and Souza (2010). The pits were prepared with $20 \mathrm{~L}$ of aged cattle manure, $15 \mathrm{~g}$ of $\mathrm{N}, 18 \mathrm{~g}$ of $\mathrm{K}_{2} \mathrm{O}, 12 \mathrm{~g}$ of $\mathrm{P}_{2} \mathrm{O}_{5}, 4 \mathrm{~g}$ of $\mathrm{Zn}, 2.7 \mathrm{~g}$ of $\mathrm{Mg}$ and $5.7 \mathrm{~g}$ of $\mathrm{S}$. In the growth stage, each plant received $53 \mathrm{~g}$ of $\mathrm{N}, 65 \mathrm{~g}$ of $\mathrm{K}_{2} \mathrm{O}, 28 \mathrm{~g}$ of $\mathrm{P}_{2} \mathrm{O}_{5}$ in four monthly applications and $18 \mathrm{~g}$ of magnesium sulfate at 90 days after transplantation. In the production stage, the amounts used were $72 \mathrm{~g}$ of $\mathrm{N}$ and $120 \mathrm{~g}$ of $\mathrm{K}_{2} \mathrm{O}$ in four monthly applications and $60 \mathrm{~g}$ of $\mathrm{P}_{2} \mathrm{O}_{5}$ in two applications together with the first and third fertilization with $\mathrm{N}$ and $\mathrm{K}$, and $18 \mathrm{~g}$ of magnesium sulfate at 150 days after transplantation. Calcium doses were divided into five equal applications, the first during the preparation of the pits and the others at $60,90,120$ and 150 days after transplantation. The fertilizers used were urea $(45 \% \mathrm{~N})$, calcium nitrate $(15.5 \% \mathrm{~N}$ and $19 \% \mathrm{Ca})$, potassium chloride $(60 \%$ $\left.\mathrm{K}_{2} \mathrm{O}\right)$, monoammonium phosphate $(11 \% \mathrm{~N}$ and $50 \%$ $\left.\mathrm{P}_{2} \mathrm{O}_{5}\right)$, zinc sulfate $(20 \% \mathrm{Zn}$ and $9 \% \mathrm{~S})$ and magnesium sulfate $(9 \% \mathrm{Mg}$ and $13 \% \mathrm{~S})$.

Irrigation was based on crop evapotranspiration (ETc), calculated by the product of reference evapotranspiration (ETo), crop coefficient in each phenological stage (kc) and area reduction coefficient $(\mathrm{ETc}=$ ETo $\mathrm{x} \mathrm{kc} \times \mathrm{kr})$. 
Reference evapotranspiration was obtained by the product of class A pan evaporation readings and the tank correction factor of 0.75 . The crop coefficients were 0.43 in the vegetative stage, 0.94 in flowering and 1.04 in fruiting. The reduction coefficient was based on the decrease in the wetting area of the localized irrigation (STEDUTO et al., 2012).

Irrigation was applied by four pressurecompensating drippers per plant, with individual flow rate of $10 \mathrm{~L} \mathrm{~h}^{-1}$ at operating pressure of 0.15 $\mathrm{MPa}$. Non-saline water (electrical conductivity ECiw of $0.3 \mathrm{dS} \mathrm{m}^{-1}$ ) was obtained from a surface spring, whereas saline water (ECiw of $4.0 \mathrm{dS} \mathrm{m}^{-1}$ ) was prepared by the dilution of iodine-free $\mathrm{NaCl}$ in plastic boxes with a capacity for $3 \mathrm{~m}^{3}$. In treatments with saline water, $10 \%$ was added to the irrigation depth to leach the salts from the root environment.

At 142 days after transplanting the seedlings, when the orchard was in full bloom and beginning of fruiting, the productive or tertiary branches (PB) were counted. Harvests were carried out three times a week, from April to July 2016, and the fruits were harvested as their rinds began to turn yellow. Weekly yield data were used to determine the indices of early ripening (IE) and concentrated cropping (IC) according to (Equations 1 and 2), respectively (KHANIZADEH; FANOUS, 1992).

$$
I E=\sum_{i=1}^{n}\left(\frac{Y_{i}}{D_{i}}\right) / n
$$

Equation 1

Where,

$\mathrm{IE}=$ Index of early ripening;

$\mathrm{i}=1,2, \ldots, \mathrm{n}$;

$\mathrm{n}=$ number of harvests;

$\mathrm{Yi}=$ yield of harvest $\mathrm{i}$;

$\mathrm{Di}=$ period from the beginning to end of harvest (days).

$$
I C=\frac{\sqrt{\sum_{i-1}^{n}\left(Y_{i}-Y\right) 2 / n}}{n}
$$

Equation 2

Where:

$\mathrm{IC}=$ Index of concentrated cropping;

$\mathrm{i}=1,2, \ldots, \mathrm{n}$,

$\mathrm{n}=$ number of harvests,

$\mathrm{Yi}=$ percentage yield at harvest $\mathrm{i}$,

$\mathrm{Y}=$ average percentage yield for number of harvests.

Data of harvests were also used to obtain: number of fruits per plant (NFP), dividing the total number of fruits harvested by the number of plants in the subplot; average fruit weight (AFW), ratio between the total fruit weight and number of fruits, with results expressed in grams and; yield (Y), through the product between the number of fruits per plant, average fruit weight (AFW) and population density, expressed in $\mathrm{tha}^{-1}$.

The data were subjected to analysis of variance, using the $\mathrm{F}$ test $(\mathrm{p} \leq 0.05)$, to evaluate the effects of the single factors and interactions. The effects of irrigation water electrical conductivity and lateral protection of the pits against water losses were compared by $\mathrm{F}$ test $(\mathrm{p} \leq 0.05)$, while calcium doses were fitted by linear regression, using the $F$ test $(p \leq 0.10)$ to verify the significance of the models. The analyses were carried out in the software program SAS ${ }^{\circledR}$ University Edition.

\section{RESULTS AND DISCUSSION}

The interaction between the electrical conductivity of irrigation water (ECiw), calcium fertilization (C) and lateral protection of pits $(\mathrm{P})$ was significant for the number of productive branches (PB), index of early ripening (IE), number of fruits per plant (NFP), average fruit weight (AFW) and yield (Y) (Table 1). Only for the index of concentrated cropping (IC) there were no effects of the factors.

The number of productive branches of yellow passion fruit, at 142 days after transplanting the seedlings, cultivated in unprotected pits and irrigated with saline water $\left(4.0 \mathrm{dS} \mathrm{m}^{-1}\right)$ was on average 40 branches (Figure 2A). Under irrigation with nonsaline water $\left(0.3 \mathrm{dS} \mathrm{m} \mathrm{m}^{-1}\right)$, the number of branches increased from 33 to a maximum of 39 branches, an $18 \%$ increase from the condition without fertilization to the calcium dose of $80 \mathrm{~kg} \mathrm{ha}^{-1}$, respectively. In pits with lateral protection, the productive branches changed from 39 to 47 under calcium doses of 0 and $120 \mathrm{~kg} \mathrm{ha}^{-1}$, respectively, that is, a $21 \%$ increase under irrigation with non-saline water (Figure 2B). When these pits were irrigated with saline water, an average of 35 branches per plant was obtained.

When irrigating yellow passion fruit using water with electrical conductivity from 0.5 to $4.5 \mathrm{dS}$ $\mathrm{m}^{-1}$, Dias et al. (2013) found no effect of salinity, noting that the increase in the number of productive branches was related to the period of evaluation. These authors observed that the increase in water salinity reduced the length of internodes on the branches and the floral buds. However, Freire et al. (2012) observed that the increase in irrigation water electrical conductivity reduced the number of productive branches. 
M. A. F. BEZERRA et al.

Table 1. Summary of the analysis of variance (Mean Square) for productive branches (PB), index of early ripening (IE), index of concentrated cropping (IC), number of fruits per plant (NFP), average fruit weight (AFW) and yield (Y) of yellow passion fruit, cultivar BRS GA1, in relation to the factors irrigation water electrical conductivity (ECiw), lateral protection of pits $(\mathrm{P})$ and fertilization with calcium $(\mathrm{C})$.

\begin{tabular}{|c|c|c|c|c|c|c|c|}
\hline $\begin{array}{l}\text { Sources of } \\
\text { Variation }\end{array}$ & DF & PB & $\mathrm{IE}$ & $\mathrm{IC}$ & NFP & AFW & $\mathrm{Y}$ \\
\hline Block & 3 & $17.4124^{\mathrm{ns}}$ & $245.6058^{\mathrm{ns}}$ & $0.0503^{\mathrm{ns}}$ & $98.4917^{\text {ns }}$ & 1127.6104 & $30.1153^{\mathrm{ns}}$ \\
\hline ECiw & 1 & $133.0256^{\mathrm{ns}}$ & $13409.0 * *$ & $0.0005^{\mathrm{ns}}$ & $2126.6781 * *$ & 2336.2317 & $479.5919 * *$ \\
\hline Residual (a) & 3 & 57.6814 & 186.4696 & 0.0266 & 24.8734 & 400.1979 & 3.6839 \\
\hline Calcium (C) & 4 & $208.6771 * *$ & $625.7917 * *$ & $0.0172^{\mathrm{ns}}$ & $304.3707 *$ & $955.1542 *$ & $31.9561 *$ \\
\hline Prot. (P) & 1 & $4.9638^{\mathrm{ns}}$ & $922.1335 * *$ & $0.0069^{\mathrm{ns}}$ & $1007.1116^{* *}$ & 431.7385 & $189.7576 * *$ \\
\hline $\mathrm{P} \times \mathrm{C}$ & 4 & $72.0594 *$ & $181.5404^{\mathrm{ns}}$ & $0.0295^{\mathrm{ns}}$ & $233.0090^{\mathrm{ns}}$ & 158.8008 & $35.0761 *$ \\
\hline ECiw x C & 4 & $128.3799 * *$ & $2907.5911 * *$ & $0.0299^{\mathrm{ns}}$ & $370.0664 *$ & $1055.6219 * *$ & $59.8100 * *$ \\
\hline ECiw x P & 1 & $0.4256^{\mathrm{ns}}$ & $143.7127^{\mathrm{ns}}$ & $0.0001^{\mathrm{ns}}$ & $342.0472^{\mathrm{ns}}$ & $1588.0675^{*}$ & $5.604^{\mathrm{ns}}$ \\
\hline ECiw x P x C & 4 & $89.8820 * *$ & $372.5969 *$ & $0.0040^{\mathrm{ns}}$ & $576.2284 * *$ & $1554.9581 * *$ & $86.4665 * *$ \\
\hline Residual (b) & 54 & 23.2253 & 121.8383 & 0.0129 & 103.8212 & 273.6795 & 11.2909 \\
\hline $\mathrm{CV}(\mathrm{a})$ & & 19.99 & 27.31 & 20.91 & 8.77 & 9.12 & 9.27 \\
\hline CV (b) & & 12.68 & 22.08 & 14.56 & 17.91 & 7.54 & 16.23 \\
\hline Means & & 38 & 50 & 0.78 & 56.9 & $219.3 \mathrm{~g}$ & $20.7 \mathrm{tha}^{-1}$ \\
\hline
\end{tabular}

ns,$*$ and **: not significant and significant at 5 and $1 \%$ probability levels by $\mathrm{F}$ test, respectively.
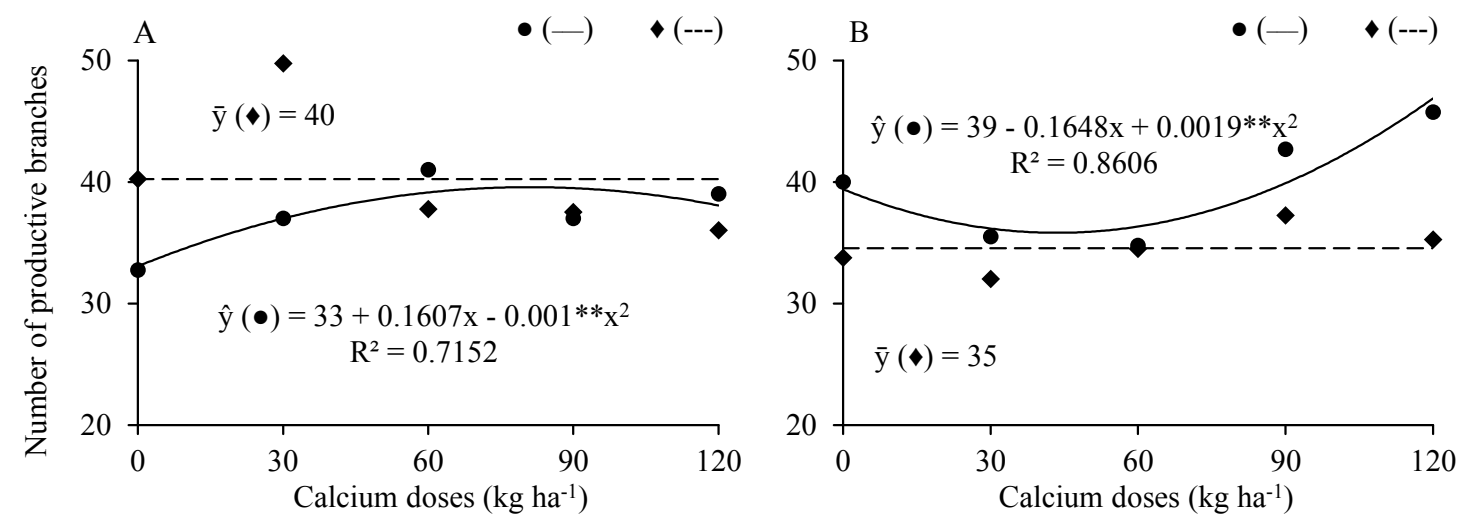

Figure 2. Number of productive branches in yellow passion fruit cv. BRS GA1 as a function of calcium doses, produced in pits without (A) and with (B) lateral protection and irrigated using water with electrical conductivity of $0.3(\bullet)$ and $4.0 \mathrm{dS}$ $\mathrm{m}^{-1}(\diamond)$.**: significant at $1 \%$ probability level by $\mathrm{F}$ test.

The index of early ripening expresses the time from planting to production, that is, the higher the index, the earlier the cultivation, while the index of concentrated cropping refers to the distribution of production during the season, and the higher the index, the more concentrated the production (KHANIZADEH; FANOUS, 1992). According to the results, the sources of variation interfered in the earliness of the orchard, but had no effect on the distribution of production. Plant earliness is directly related to genetic and environmental factors. The increase in earliness brings forward the economic return of the agricultural activity, while the reduction in the number of harvests can reduce the cost of production (KHANIZADEH; FANOUS, 1992).

In regard to calcium doses, under irrigation with $0.3 \mathrm{dS} \mathrm{m}^{-1}$ water, the indices of early ripening were maximum without the application of this macronutrient, reaching minimum values as the doses increased to 82 and $73 \mathrm{~kg} \mathrm{ha}^{-1}$ in pits without (Figure 3A) and with (Figure 3B) protection, respectively. Conversely, under irrigation with 4.0 $\mathrm{dS} \mathrm{m} \mathrm{m}^{-1}$ water in unprotected pits, there was an increase in this index from 27.6 to $50.9(84 \%)$ from the absence of calcium fertilization to the dose of 60 $\mathrm{kg} \mathrm{ha}{ }^{-1}$ (Figure 3A) and, in protected pits, the increase was from 24.3 to 40.8 (68\%) without calcium fertilization and with the application of 83 $\mathrm{kg} \mathrm{ha}^{-1}$ (Figure 3B).

The reduction in the index of early ripening caused by fertilization with calcium, under irrigation with non-saline water, may be related to the decrease in the rate of growth and ripening of fruits. Pereira et al. (2017) observed that the increase in the number of fruits in the plant leads to the production of smaller fruits. Salt stress reduces passion fruit growth in the stages of both seedlings (BEZERRA et al., 2019) and plants in the field (FREIRE et al., 2012), delaying and/or inhibiting the production and formation of productive branches, flowering, fruiting and beginning of harvest. Results have recorded delays in main stem pruning of 6 days (DIAS et al., 2013) and 12 days (FREIRE et al., 2012) as the electrical conductivity of irrigation water increases from 0.5 to $4.5 \mathrm{dS} \mathrm{m}^{-1}$, besides the reduction in the length of internodes on the productive branches, on average by $7 \mathrm{~mm}$ (DIAS et al., 2013). Freire et al. (2012) also found reduction of $9 \%$ in the rate of growth in passion fruit height caused by salinity. 

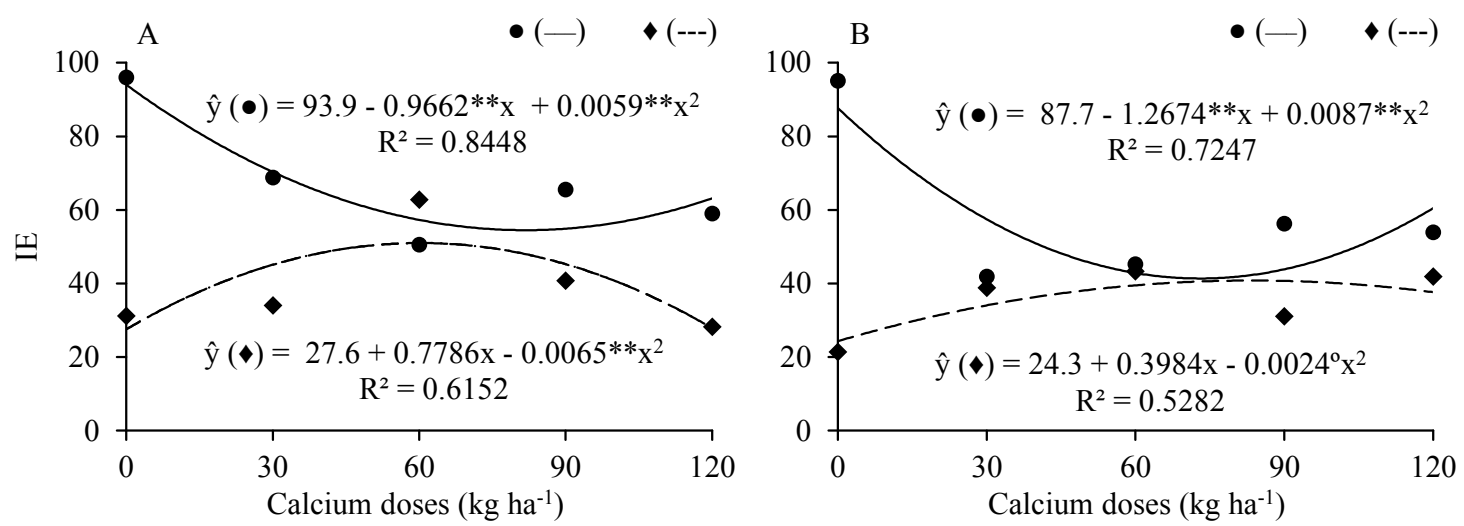

Figure 3. Index of early ripening in yellow passion fruit cv. BRS GA1 as a function of calcium doses, produced in pits without (A) and with (B) lateral protection and irrigated using water with electrical conductivity of $0.3(\bullet)$ and $4.0 \mathrm{dS} \mathrm{m}$ $(\diamond){ }^{\circ}$ and $* *$ : significant at 10 and $1 \%$ probability levels by $\mathrm{F}$ test, respectively.

The number of fruits, in plants grown in unprotected pits and irrigated with non-saline water, was on average 63 fruits (Figure 4A). Under irrigation with saline water $\left(4.0 \mathrm{dS} \mathrm{m}^{-1}\right)$, calcium promoted increase in the amount of fruits, with maximum of 67 fruits under application of $53 \mathrm{~kg} \mathrm{ha}^{-1}$ of calcium. For plants grown in laterally lined pits and irrigated with non-saline water, the number of fruits harvested increased on average by 1.8 fruits per plant with each increase of $10 \mathrm{~kg} \mathrm{ha}^{-1}$ of calcium, reaching a maximum value of 71 fruits with application of $120 \mathrm{~kg} \mathrm{ha}^{-1}$ of calcium (Figure 4B). However, when plants were irrigated with saline water there was no effect of calcium, with an average of 46 fruits per plant.
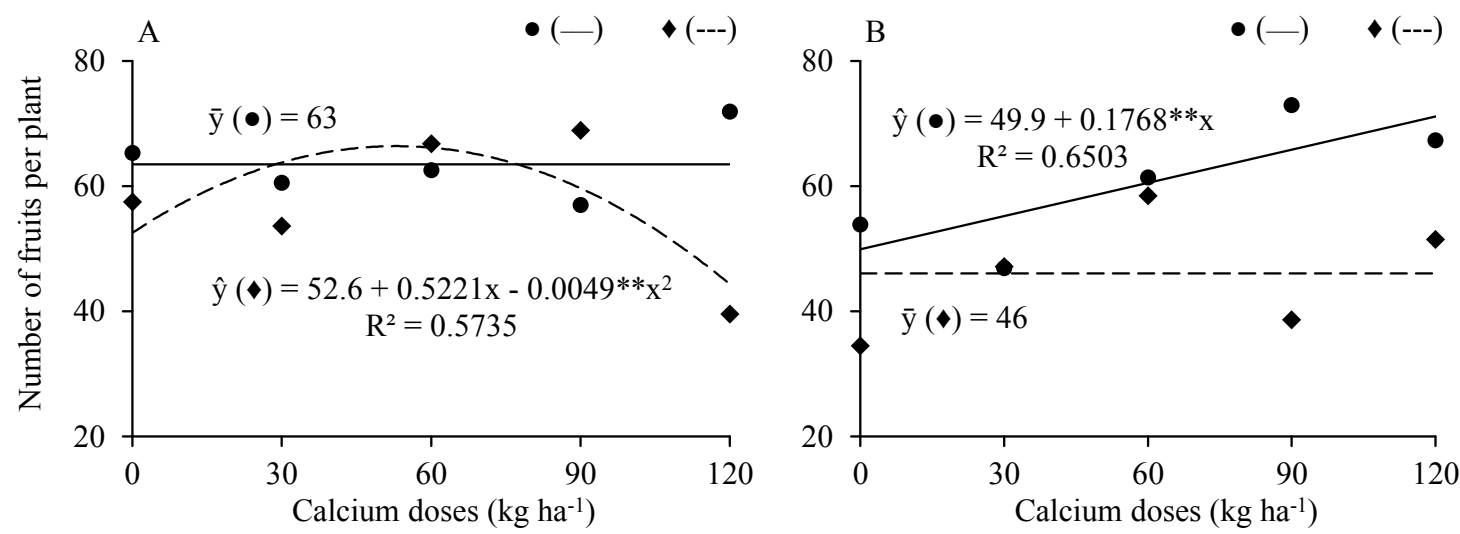

Figure 4. Number of fruits per plant in yellow passion fruit cv. BRS GA1 as a function of calcium doses, produced in pits without (A) and with (B) lateral protection and irrigated using water with electrical conductivity of $0.3(\bullet)$ and $4.0 \mathrm{dS} \mathrm{m}^{-1}$ $(\bullet)$. **: significant at $1 \%$ probability level by $\mathrm{F}$ test.

The number of fruits on the plant is related to intrinsic factors of the crop (CAVALCANTE et al., 2016) and environmental factors; for the number of fruits per plant, it is possible to mention the production of productive branches, production of flower, pollination and fruit set. As observed by Hafle et al. (2009), the decrease in the productive branches reduces the production of fruits in passion fruit. Thus, it was observed that the effect of salt stress on fruit production may be related to both the reduction in the number of productive branches (FREIRE et al., 2012) and the reduction in the length of internodes on the branches and floral buds (DIAS et al., 2013). Dias et al. (2012) found that the increase of $1 \mathrm{dS} \mathrm{m}^{-1}$ in the electrical conductivity of irrigation water reduced, on average, three fruits in the passion fruit. As for calcium, for being an essential nutrient and acting in the growth of the pollen tube (TAIZ et al., 2017), its deficiency may compromise production. This statement is in agreement with Cavalcante et al. (2014, 2015), who found higher fruit production in yellow passion fruit under foliar application of calcium.

For the average fruit weight, the increase in calcium doses for plants grown in unprotected pits and irrigated with non-saline water reduced fruit weight by $0.22 \mathrm{~g}$ for each $\mathrm{kg}^{-1}$ of the nutrient applied (Figure 5A). The loss of fruit weight caused by salinity, observed in unprotected pits, was mitigated by calcium. In this situation, the lowest fruit weight was equal to $186 \mathrm{~g}$ without calcium application, changing to a maximum of $227 \mathrm{~g}$ under the dose of 
$120 \mathrm{~kg} \mathrm{ha}^{-1}$, i.e., an increase of $0.34 \mathrm{~g} \mathrm{~kg}^{-1}$ per unit increase in calcium doses. In laterally lined pits, for both non-saline and saline water, no function was

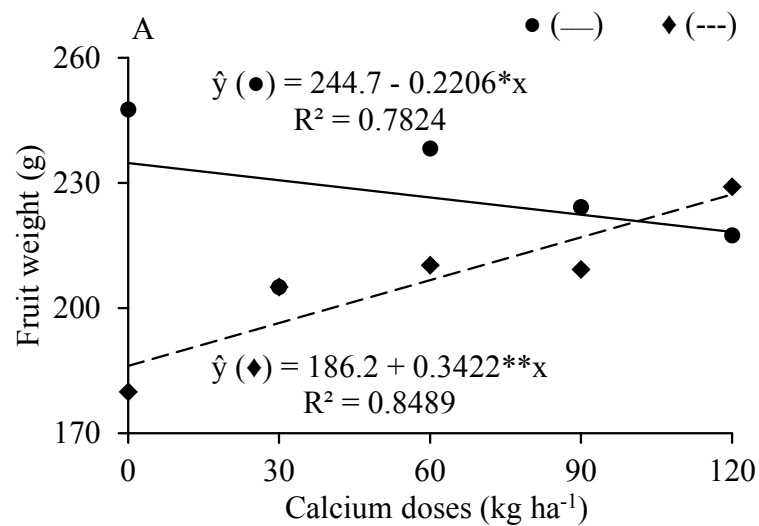

fitted between calcium doses and fruit weight, with the respective means of 217.9 and $216.0 \mathrm{~g}$ (Figure 5B).

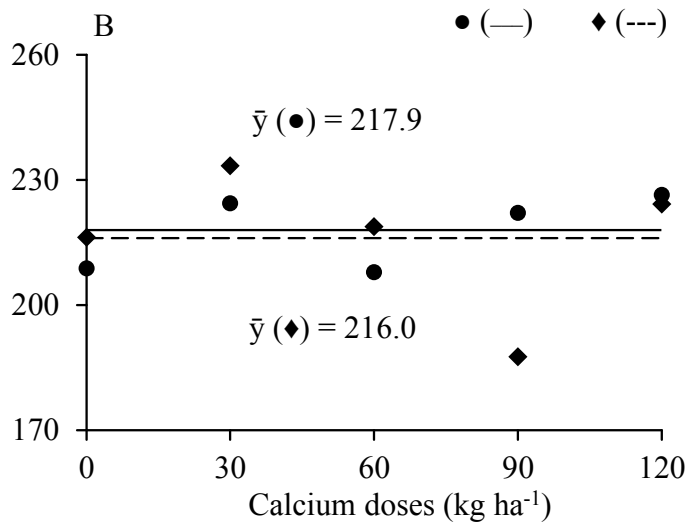

Figure 5. Average fruit weight of yellow passion fruit $\mathrm{cv}$. BRS GA1 as a function of calcium doses, produced in pits without (A) and with (B) lateral protection and irrigated using water with electrical conductivity of $0.3(\bullet)$ and $4.0 \mathrm{dS} \mathrm{m}$ $(\bullet)$. ${ }^{*}$ and ${ }^{* *}$ : significant at 5 and $1 \%$ probability levels by $\mathrm{F}$ test, respectively.

In the reproductive stage, the fruits are the main sinks of photoassimilates (TAIZ et al., 2017), and fruit weight may be reduced when the amount of fruits increases (PEREIRA et al., 2017). The reduction in net photosynthesis may reduce fruit weight. Nunes et al. (2017) observed that irrigation water salinity reduces the assimilation of carbon dioxide in yellow passion fruit plants, which may have negatively interfered in biochemical reactions that occur in the chloroplast stroma (CRUZ et al., 2017), besides reducing gas exchanges. Dias et al. (2012) observed a reduction of $12.5 \mathrm{~g}$ in passion fruit per unit increase in the electrical conductivity of irrigation water. Souza et al. (2018) observed a reduction of $9 \%$ (20 g per fruit) when the electrical conductivity of irrigation water increased from 0.35 to $4.0 \mathrm{dS} \mathrm{m}^{-1}$.

The reduction in fruit weight with increasing calcium doses under irrigation with non-saline water may be related to the interference in nutrient absorption. Cavalcante et al. (2014, 2015) observed an increase in the average weight of passion fruit when foliar application of calcium was performed at a concentration of up to $1 \mathrm{~g} \mathrm{~L}^{-1}$, with reduction after this concentration. Under irrigation with $4 \mathrm{dS} \mathrm{m} \mathrm{m}^{-1}$ water, calcium mitigated salt stress because this divalent cation, besides being antagonistic with sodium, has the energy to displace it from the soil sorption complex (FONTENELE et al., 2014), enabling its precipitation and/or leaching.

The increase in calcium doses increased passion fruit yield. Under irrigation of unprotected pits with non-saline water, the average increase in yield was $45.8 \mathrm{~kg} \mathrm{ha}^{-1}$ of fruits for each one kilogram of calcium applied, that is, the yield increased from $19.8 \mathrm{t} \mathrm{ha}^{-1}$ in the absence of calcium fertilization to $25.3 \mathrm{t} \mathrm{ha}^{-1}$ under the calcium dose of $120 \mathrm{~kg} \mathrm{ha}^{-1}$ (Figure 6A). On the other hand, under irrigation with saline water $\left(4.0 \mathrm{dS} \mathrm{m}^{-1}\right)$, calcium increased the yield up to the dose of $58 \mathrm{~kg} \mathrm{ha}^{-1}$, when $23.8 \mathrm{t} \mathrm{ha}^{-1}$ of passion fruits were obtained. For plants grown in laterally lined pits and irrigated with $0.3 \mathrm{dS} \mathrm{m}^{-1}$ water, the yield changed from 17.4 to $26.4 \mathrm{t} \mathrm{ha}^{-1}$ under the respective calcium doses of 0 and $120 \mathrm{~kg}$ $\mathrm{ha}^{-1}$, an average increase of $75 \mathrm{~kg}$ of fruits per kilogram of calcium (Figure 6B). In the combination of irrigation with saline water in laterally lined pits, there was no functional relationship between yield and calcium doses, with an average of $16.4 \mathrm{t} \mathrm{ha}^{-1}$.

Positive effects of calcium fertilization were also reported by Cavalcante et al. $(2014,2015)$, who evaluate sources and doses of calcium applied through the leaves of yellow passion fruit. Cavalcante et al. (2014) obtained maximum yields of 11.2 and $11.9 \mathrm{t} \mathrm{ha}^{-1}$ with foliar application of calcium using nitrate and calcium chloride, respectively. Calcium not only stimulated passion fruit production, but also mitigated the effect of irrigation water salinity, which was also observed by Fernandes et al. (2010).

Yellow passion fruit yield is associated with the number of fruits, which is one of the main traits of the crop (LÚCIO et al., 2013), and in this case, the cited authors found Pearson correlation $(\rho)$ of $0.92(t$ $=21.25 ; \mathrm{p}<0.0001)$ between the number of fruits per plant and yield, while for its correlation with the average fruit weight the authors found $\rho=0.30(\mathrm{t}=$ $2.80 ; \mathrm{p}=0.0064)$. Based on the above, salinity reduced the yield mainly through the reduction in fruit production. This reduction is in agreement with Dias et al. (2012), who observed a $37 \%$ loss in passion fruit production, with the increase in the electrical conductivity of irrigation water from 0.5 to $4.5 \mathrm{dS} \mathrm{m}^{-1}$. On the other hand, Nunes et al. (2017) found no significant variation in the yield of yellow passion fruit irrigated using water with electrical conductivity levels of 0.35 and $4.0 \mathrm{dS} \mathrm{m}^{-1}$. 

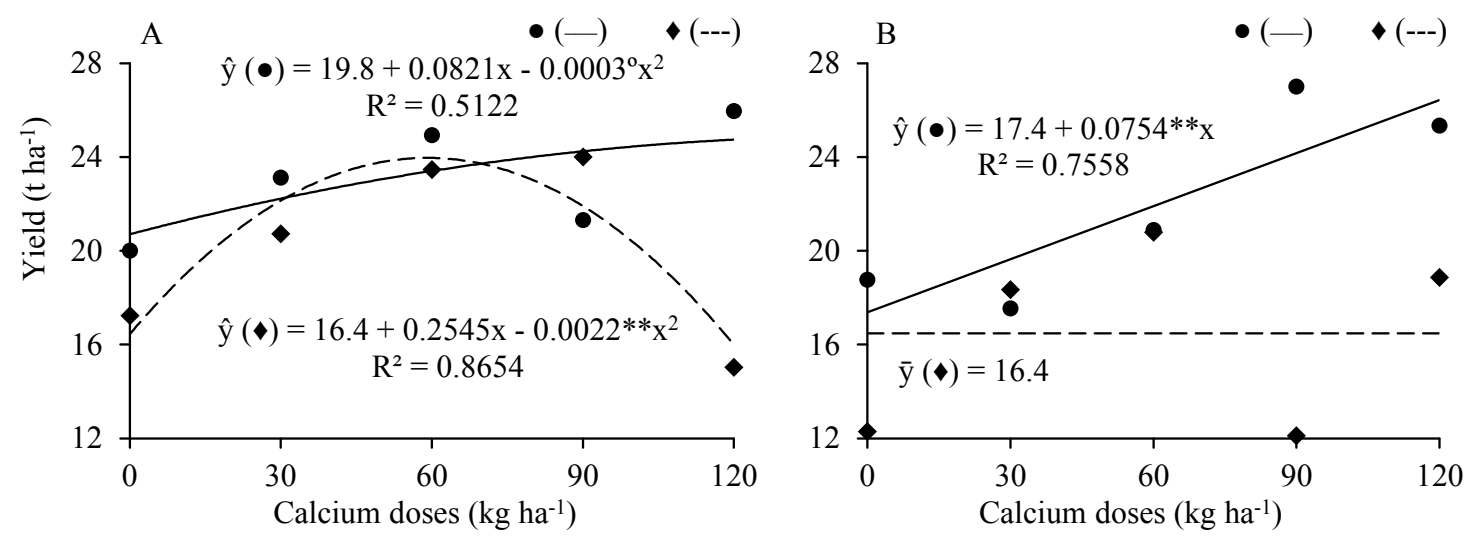

Figure 6. Yield of yellow passion fruit cv. BRS GA1 as a function of calcium doses, produced in pits without (A) and with (B) lateral protection and irrigated using water with electrical conductivity of $0.3(\bullet)$ and $4.0 \mathrm{dS} \mathrm{m}^{-1}(\bullet) .{ }^{\circ}$ and ${ }^{* *}$ : significant at 10 and $1 \%$ probability levels by $\mathrm{F}$ test, respectively.

\section{CONCLUSIONS}

Saline water delays harvest, reduces the number and weight of fruits and yield of yellow passion fruit cv. BRS GA1.

Increase of calcium in Entisol with low content of this macronutrient promotes positive effects on passion fruit production components.

Lateral protection of the pits reduces the yield of yellow passion fruit, and the reduction is intensified under irrigation with saline water.

Application of up to $60 \mathrm{~kg} \mathrm{ha}^{-1}$ of calcium attenuates the effects of irrigation with saline water on passion fruit production.

\section{ACKNOWLEDGMENTS}

The present study was conducted with support from Coordenação de Aperfeiçoamento de Pessoal de Nível Superior - Brasil (CAPES) and Conselho Nacional de Desenvolvimento Científico e Tecnológico (CNPq).

\section{REFERENCES}

ALDON, D. et al. Calcium Signalling in Plant Biotic Interactions. International Journal of Molecular Sciences, 19: 665-684, 2018.

ALVARES, C. A. et al. Köppen's climate classification map for Brazil. Meteorologische Zeitschrift, 22: 711-728, 2013.

BEZERRA, M. A. F. et al. Nitrogen as a mitigator of salt stress in yellow passion fruit seedlings. Semina: Ciências Agrárias, 40: 611-622, 2019.

BORGES, A. L.; SOUZA, L. S. Recomendação de calagem e adubação para maracujazeiro. 1. ed. Cruz das Almas, BA: Embrapa Mandioca e
Fruticultura Tropical, 2010. 4 p. (Comunicado Técnico, 141).

CAVALCANTE, L. F. et al. Produção do maracujazeiro-amarelo irrigado com água salina em covas protegidas contra perdas hídricas. Irriga, 10: 229-240, 2005b.

CAVALCANTE, L. F. et al. Produção e composição mineral do maracujazeiro amarelo com adubação foliar de cálcio - segunda safra. Revista Agropecuária Técnica, 36: 35-49, 2015.

CAVALCANTE, L. F. et al. Produção e composição mineral do maracujazeiro amarelo com adubação foliar de cálcio - primeira safra. Revista Agropecuária Técnica, 35: 69-80, 2014.

CAVALCANTE, L. F. et al. Resposta do maracujazeiro amarelo à salinidade da água sob diferentes formas de plantio. Revista Brasileira de Engenharia Agrícola e Ambiental, 9: 314-317, 2005a.

CAVALCANTE, N. R. et al. Productivity, fruit physicochemical quality and distinctiveness of passion fruit populations. Revista Brasileira de Fruticultura, 38: e-142, 2016.

CRUZ, J. L. et al. Salinity reduces carbon assimilation and the harvest index of cassava plants (Manihot esculenta Crantz). Acta Scientiarum, 39: $545-555,2017$.

DIAS, T. J. et al. Qualidade física e produção do maracujá amarelo em solo com biofertilizante irrigado com águas salinas. Semina: Ciências Agrárias, 33: 2905-2918, 2012.

DIAS, T. J. et al. Irrigação com água salina em solo com biofertilizante bovino no crescimento do maracujazeiro amarelo. Semina: Ciências Agrárias, 34: 1639-1652, 2013 
FALEIRO, F. G.; JUNQUEIRA, N. T. V. (Ed.). Maracujá: o produtor pergunta, a Embrapa responde. 1. ed. Brasília, DF: Embrapa, 2016. 341 p.

FERNANDES, O. B. et al. Efeito do nitrato de cálcio na redução do estresse salino no meloeiro. Revista Caatinga, 23: 93-103, 2010.

FONTENELE, A. J. P. B. et al. Growth of cowpea plants inoculated with Rhizobium in a saline-sodic soil after application of gypsum. Revista Ciência Agronômica, 45: 499-507, 2014.

FREIRE, J. L. O. et al. Crescimento do maracujazeiro amarelo sob estresse salino e biofertilização em ambiente protegido contra perdas hídricas. Holos, 28: 55-68, 2012.

FREIRE, J. L. O. et al. Necessidade hídrica do maracujazeiro amarelo cultivado sob estresse salino, biofertilização e cobertura do solo. Revista Caatinga, 24: 82-91, 2011.

HAFLE, O. M. et al. Produtividade e qualidade de frutos do maracujazeiro-amarelo submetido à poda de ramos produtivos. Revista Brasileira de Fruticultura, 31: 763-770, 2009.

HOLANDA, J. S. et al. S. Qualidade da água para irrigação. In: GHEYI, H. R. et al. (Eds.). Manejo da Salinidade na Agricultura: estudos básicos e aplicados. $2^{\mathrm{a}}$ ed. Fortaleza: INCTSal, 2016. cap. 4, p. 35-50.

INSTITUTO BRASILEIRO DE GEOGRAFIA E ESTATÍSTICA - IBGE. Produção Agrícola Municipal. Lavouras Permanentes 2018. Disponível em: < https://sidra.ibge.gov.br/Tabela/1613 >. Acesso em: 25 out. 2019.

KADER, Md. A.; LINDBERG, S. Cytosolic calcium and $\mathrm{pH}$ signaling in plants under salinity stress. Plant Signaling \& Behavior, 5: 233-238; 2010.

KHANIZADEH, S.; FANOUS, M. A. Mathematical indices for comparing small fruit crops for harvest time and trait similarity. HortScience, 27: 346-348, 1992.

LÚCIO, A. D. C. et al. Relações entre os caracteres de maracujazeiro-azedo. Ciência Rural, 43: 225232, 2013.

NUNES, J. C. et al. Gas exchange and productivity of yellow passion fruit irrigated with saline water and fertilized with potassium and biofertilizer. Ciencia e Investigación Agraria, 44: 168-183, 2017.
PEREIRA, A. M. et al. Characteristics of muskmelon fruits in relation to temporary row cover and the number of fruits. Horticultura Brasileira, 35: 591-598, 2017.

SOUZA, J. T. A. et al. Effects of water salinity and organomineral fertilization on leaf composition and production in Passiflora edulis. Revista Brasileira de Engenharia Agrícola e Ambiental, 22: 535-540, 2018.

STEDUTO, P. et al. Crop yield response to water. 1. ed. Rome, Itália: FAO, 2012. 500 p. (Estudio FAO: Riego y Drenaje, 66).

TAIZ, L. et al. Fisiologia e desenvolvimento vegetal. 6. ed. Porto Alegre, RS: Artmed, 2017. 858 p.

TIAN, X. et al. Application of nitric oxide and calcium nitrate enhances tolerance of seedlings to salt stress. Plant Growth Regulation, 77: 343-356, 2015. 